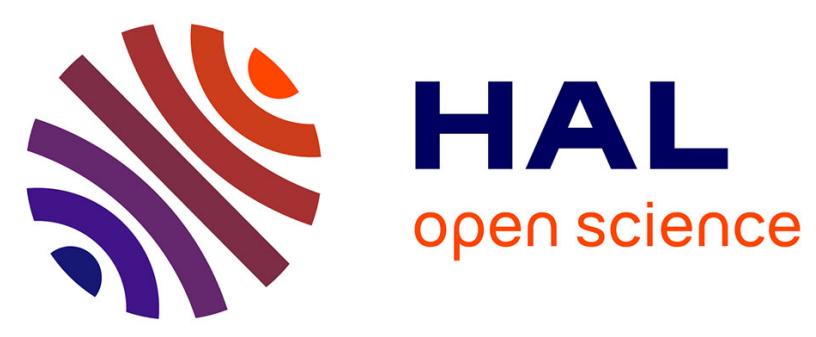

\title{
BIOCHEMICAL CHARACTERISTICS OF A DIFFUSIBLE FACTOR THAT INDUCES GAMETOPHYTE TO SPOROPHYTE SWITCHING IN THE BROWN ALGA ECTOCARPUS
}

Haiqin Yao, Delphine Scornet, Murielle Jam, Cécile Hervé, Philippe Potin, Lydie Oliveira Correia, Susana M Coelho, J. Mark Cock

\section{To cite this version:}

Haiqin Yao, Delphine Scornet, Murielle Jam, Cécile Hervé, Philippe Potin, et al.. BIOCHEMICAL CHARACTERISTICS OF A DIFFUSIBLE FACTOR THAT INDUCES GAMETOPHYTE TO SPOROPHYTE SWITCHING IN THE BROWN ALGA ECTOCARPUS. Journal of Phycology, 2021, 57 (3), pp.742-753. 10.1111/jpy.13126 . hal-03089431

\section{HAL Id: hal-03089431 \\ https://cnrs.hal.science/hal-03089431}

Submitted on 28 Dec 2020

HAL is a multi-disciplinary open access archive for the deposit and dissemination of scientific research documents, whether they are published or not. The documents may come from teaching and research institutions in France or abroad, or from public or private research centers.
L'archive ouverte pluridisciplinaire HAL, est destinée au dépôt et à la diffusion de documents scientifiques de niveau recherche, publiés ou non, émanant des établissements d'enseignement et de recherche français ou étrangers, des laboratoires publics ou privés. 


\section{BIOCHEMICAL CHARACTERISTICS OF A DIFFUSIBLE FACTOR THAT INDUCES GAMETOPHYTE TO SPOROPHYTE SWITCHING IN THE BROWN ALGA ECTOCARPUS}

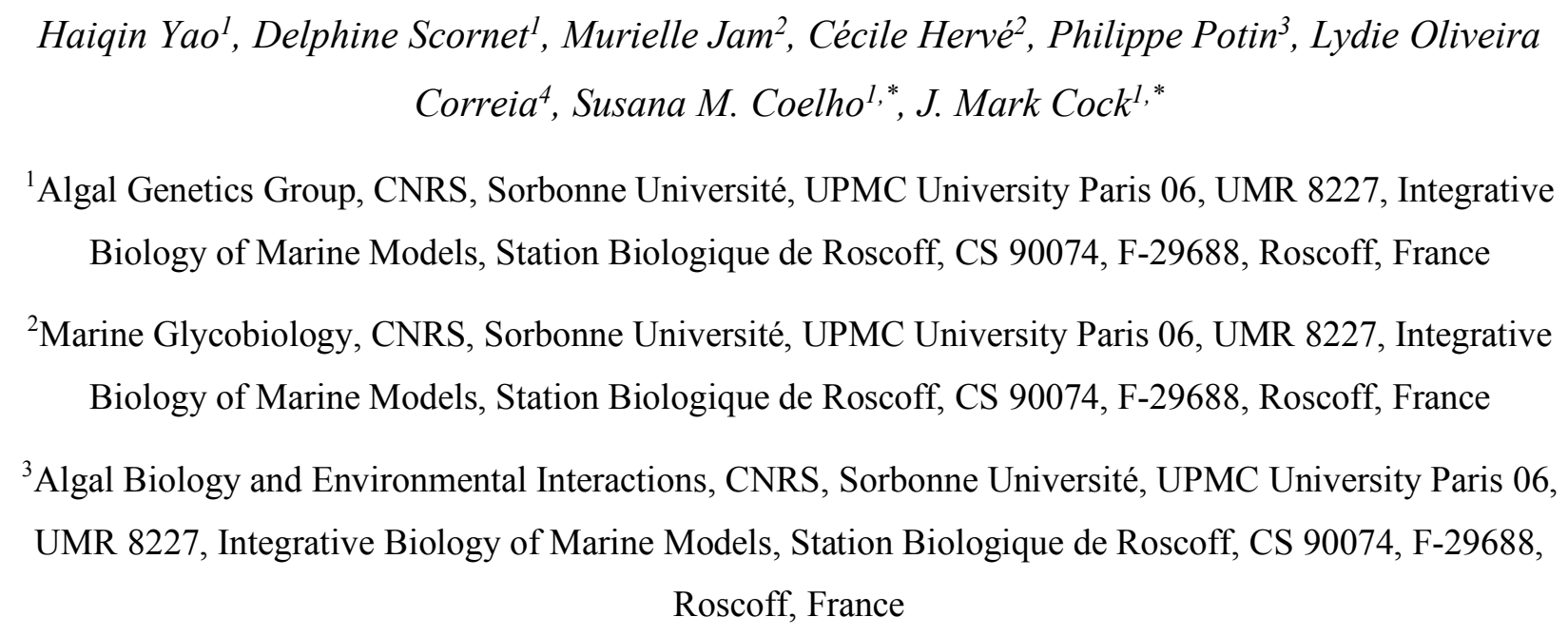




\section{ABSTRACT}

The haploid-diploid life cycle of the filamentous brown alga Ectocarpus involves alternation between two independent and morphologically distinct multicellular generations, the sporophyte and the gametophyte. Deployment of the sporophyte developmental program requires two TALE homeodomain transcription factors OUROBOROS and SAMSARA. In addition, the sporophyte generation has been shown to secrete a diffusible factor that can induce uni-spores to switch from the gametophyte to the sporophyte developmental program. Here, we determine optimal conditions for production, storage and detection of this diffusible factor and show that it is a heat-resistant, high molecular weight molecule. Based on a combined approach involving proteomic analysis of sporophyte-conditioned medium and the use of biochemical tools to characterize arabinogalactan proteins, we present evidence that sporophyte-conditioned medium contains AGP epitopes and suggest that the diffusible factor may belong to this family of glycoproteins.

Key index words: arabinogalactan protein, diffusible factor, Ectocarpus, gametophyte, life cycle, sporophyte

Abbreviations: ACN, acetonitrile; AGP, arabinogalactan protein; LC-MS/MS, liquid chromatography coupled to mass spectrometry; ORO, OUROBOROS; PES, Provasoli-enriched natural seawater; SAM, SAMSARA; SCM, sporophyte-conditioned medium; SDS-PAGE, sodium dodecyl sulfatepolyacrylamide gel electrophoresis; TALE HD TF, three amino acid loop extension homeodomain transcription factor; TFA, trifluoroacetic acid, WSC, wall sensing component.

Most eukaryotic life cycles involve an alternation between haploid and diploid phases, with the transitions between ploidy states occurring as a result of meiotic division (ploidy reduction) and gamete fusion, or syngamy (increased ploidy; Coelho et al. 2007). Multicellular photosynthetic organisms with haploid-diploid life cycles produce two distinct multicellular generations, one during each phase of the life cycle: diploid, spore-producing sporophytes and haploid, gamete-producing gametophytes (Coelho et al. 2007, Cock et al. 2014). The majority of brown algae have this type of haploid-diploid life cycle and one of these species, the filamentous brown alga Ectocarpus sp., is being used as a model system to study life cycle regulation (Peters et al. 2004, Cock et al. 2014, Coelho and Cock 2020). Ectocarpus has a complex life cycle (Müller 1967). In addition to the basic sexual life cycle, involving an alternation between gametophyte and sporophyte 
generations, several asexual variations have been observed in culture, including parthenogenetic development of gametes that fail to fuse with a gamete of the opposite sex (Müller 1967). Interestingly, germinating parthenogenetic gametes deploy the sporophyte program, despite being haploid, to produce partheno-sporophyte individuals that are morphologically indistinguishable from diploid sporophytes. Moreover, these individuals not only resemble sporophytes morphologically but are functional sporophyte thalli, producing spores and not gametes (Müller 1967, Bothwell et al. 2010). One important conclusion that can be drawn from the existence of haploid partheno-sporophytes is that life cycle generation (i.e. deployment of a gametophyte or a sporophyte bodyplan) is not determined by ploidy (i.e. whether the organism is in the haploid or diploid phase) and that these two features of the life cycle can be uncoupled under certain circumstances (Müller 1967, Bothwell et al. 2010). This conclusion is supported by the existence of genetic mutants that cause switching between life cycle generations, independent of the ploidy of the mutant individual (Coelho et al. 2011, Arun et al. 2019). Genetic analysis of life cycle mutants of this type has demonstrated that the deployment of the sporophyte program in Ectocarpus is under the control of two homeodomain transcription factors (HD TFs) of the three amino acid loop extension (TALE) class, which have been named OUROBOROS (ORO) and SAMSARA (SAM), respectively (Coelho et al. 2011, Arun et al. 2019). These transcription factors appear to be derived from an extremely ancient life cycle regulation system and to be distantly related to HD TF life cycle regulators in other eukaryotic supergroups such as specific KNOX and BEL class proteins in the green lineage (Viridiplantae).

Further evidence for the independence of life cycle generation and ploidy was provided by the identification of a sporophyte-inducing factor that is secreted into the surrounding seawater medium by Ectocarpus sporophytes in culture (Arun et al. 2013). When uni-spores (i.e. spores produced by unilocular sporangia), which normally develop to produce the gametophyte generation, are allowed to germinate in the presence of this diffusible factor, a proportion of the resulting germlings deploy the sporophyte developmental pathway. Interestingly, uni-spores carrying either oro or sam mutations are resistant to the action of the diffusible, sporophyte-inducing factor (Arun et al. 2013, 2019), indicating that the $O R O$ and $S A M$ genes are necessary for developmental reprogramming to occur. ORO and SAM may therefore be part of the regulatory network trigged by the sporophyte-inducing factor.

The objective of this study was to further characterise the diffusible sporophyte-inducing factor. After optimising production, storage and bioassay of the factor, we carried out a number of analyses aimed at providing further information about its biochemical nature. We obtained evidence that the sporophyteinducing factor is a high molecular weight molecule that is resistant to high temperature and protease treatment. Interestingly, mass spectrometry analysis of partially purified (ultrafiltrated) sporophyteconditioned medium (SCM) identified 36 proteins, one of which is predicted to contain an arabinogalactan protein (AGP) core protein domain. Furthermore, AGP glycan epitopes were detected in a concentrated SCM preparation using immunoblotting and SCM activity was reduced following incubation with an AGP-reactive 
Yariv reagent. Taken together, these observations led us to suggest that the diffusible factor may correspond to an AGP.

\section{MATERIALS AND METHODS}

Biological material and preparation of SCM. The biological material used in this study corresponded to partheno-sporophytes and gametophytes of Ectocarpus sp. strain Ec32, which is a male descendant of a diploid sporophyte Ec17 (CCAP1310/193) isolated at San Juan de Marcona, Peru (Peters et al. 2008). The original Ec32 gametophyte was derived from a uni-spore produced in a unilocular sporangium on the diploid sporophyte parent strain Ec17. In the unilocular sporangia of diploid sporophytes, uni-spores are produced by a single meiotic division followed by several mitotic divisions. The spores can therefore be termed unispores (derived from a unilocular sporangium) or meio-spores (derived meiotically). Parthenogenetic development of male gametes, produced in plurilocular gametangia on the original Ec32 gametophyte, gave rise to the Ec32 partheno-sporophyte strain, which is maintained in culture by asexual reproduction either by thallus fragmentation or through mitotically-derived mito-spores produced in plurilocular sporangia. Ec32 gametophytes were derived from Ec32 partheno-sporophytes through the production of uni-spores in unilocular sporangia. A previous study (Bothwell et al. 2010) showed that partheno-sporophytes can produce uni-spores in two different ways: either the partheno-sporophyte undergoes endoreduplication during early development to become diploid, allowing normal meiotic divisions to occur in the unilocular sporangia or the thallus remains haploid, in which case the first division of the uni-spore mother cell is apomeiotic (a meiotic division without reduction). Both of these processes produce haploid uni-spores which develop as gametophytes.

Strain Ec32 was cultivated in Provasoli-enriched natural seawater (PES) under standard culture conditions at $13^{\circ} \mathrm{C}$, with a $12 \mathrm{~h} / 12 \mathrm{~h}$ day/night cycle of white fluorescent light at $20 \mu \mathrm{M}$ photons $/ \mathrm{m}^{2} \cdot \mathrm{s}$ (Coelho et al. 2012). Strain Ec32 carries a V sex chromosome and is therefore male when in the gametophyte generation.

The standard conditions for the production of SCM (Yao et al. 2020) involved inoculating $160 \mathrm{ml}$ of PES in a $150 \mathrm{~mm}$ Petri dish with about $10^{6}$ gametes (which germinate to produce partheno-sporophytes) and cultivating for 4 to 6 weeks under low light conditions $\left(2-3 \mu \mathrm{M}\right.$ photons $\left./ \mathrm{m}^{2} \cdot \mathrm{s}\right)$. Variations on this procedure were used to test the effect of light intensity, culture density and culture time on SCM production. The alternative light conditions used for these tests were medium light $\left(15-20 \mu \mathrm{M}\right.$ photons $\left./ \mathrm{m}^{2} \cdot \mathrm{s}\right)$ and high light (25-30 $\mu \mathrm{M}$ photons $\left./ \mathrm{m}^{2} \cdot \mathrm{s}\right)$.

To produce large volumes of SCM, $10 \mathrm{~L}$ bottles of PES were inoculated with $0.5 \mathrm{~g}$ of partheno-sporophyte material and cultured under low light conditions with aeration by pumping air through a $0.2 \mu \mathrm{m}$ filter. In this bottle system, cultures grown for between four and 11 weeks produced SCM with diffusible factor activity. 
SCM was recovered by filtering cultures through a reusable coffee filter $(12.5 \mathrm{~cm}$ Finlandek permanent coffee filter) to remove most of the partheno-sporophyte tissue and then filtering through a $40 \mu \mathrm{m}$ cell strainer (Falcon $40 \mu \mathrm{m}$ Nylon cell strainer) to remove any remaining algal cells. Finally, a $0.22 \mu \mathrm{m}$ syringe filter (Millipore Millex-GP polyethersulphone membrane) was used to remove bacteria. The SCM was then either used immediately or stored at $4^{\circ} \mathrm{C}$.

Bioassay for the diffusible sporophyte-inducing factor. Test samples of SCM were either diluted in PES or, when used undiluted, enriched in micronutrients by addition of Provasoli solution to $1 \mathrm{x}$ final concentration. One or more unilocular sporangia were micro-dissected from fertile partheno-sporophyte thalli under a binocular microscope and placed in $300 \mu 1$ of these preparations so that the uni-spores were released directly into the test solution. Each $300 \mu \mathrm{l}$ droplet represented a replicate assay of the test solution. The preparations were incubated overnight in very high light $\left(35 \mu \mathrm{mol}\right.$ photons $\left./ \mathrm{m}^{2} \cdot \mathrm{s}\right)$ to promote uni-spore release. Empty unilocular sporangia were removed after release of the uni-spores. The numbers of gametophytes and sporophytes were scored four to seven days later based on germling morphology (Peters et al. 2008) using an inverted light microscope (Olympus CKX41). In some cases when the uni-spores grew poorly, an additional $300 \mu 1$ of the test preparation was added to the drop and culture continued.

Proteinase K and heat treatment of SCM. Heat-treated SCM was autoclaved at $121^{\circ} \mathrm{C}$ for $30 \mathrm{~min}$. Proteinasetreated SCM was incubated with $100 \mu \mathrm{g} / \mathrm{ml}$ proteinase $\mathrm{K}$ at $37^{\circ} \mathrm{C}$ for $1 \mathrm{~h}$ and then autoclaved at $121^{\circ} \mathrm{C}$ for 30 min. Provasoli solution was added to the samples from both experiments to $1 \mathrm{x}$ final concentration before carrying out bioassays for the diffusible factor.

Size fractionation by ultrafiltration. SCM was pre-filtered through a $0.22 \mu \mathrm{m}$ filtration system (Stericup and Steritop, $500 \mathrm{ml}$ Millipore Express PLUSE $0.22 \mu \mathrm{m}$ PES) before ultrafiltration. Ultrafiltration was then carried out using an ÄKTA ${ }^{\mathrm{TM}}$ flux (GE Healthcare BioSciences Uppsala, Sweden) equipped with a $100 \mathrm{kDa}$, a $50 \mathrm{kDa}$ or a $10 \mathrm{kDa}$ cartridge. Batches of pre-filtered SCM, were gradually fed into the starting reservoir in order to maintain a constant volume of about $300 \mathrm{ml}$, which was cycled through the filter resin, with the filtrate being collected separately during the cycling. The $10-50 \mathrm{kDa}$ size range was obtained by filtering the flow-through from a $50 \mathrm{kDa}$ filter filtration through a $10 \mathrm{kDa}$ filter as a second step, retaining the retentate. Concentrated retentates were designated uf-SCM for ultra-filtrated SCM. To assay the activity of the diffusible factor, uf-SCM preparations were diluted in PES to obtain a concentration equivalent to 1X SCM.

Immunodot assays with anti-AGP antibodies. Serial dilutions of each test sample (five five-fold dilution steps) were carried out and $1 \mu \mathrm{L}$ aliquots of each dilution spotted onto nitrocellulose membranes 
(Amersham) along with equivalent dilutions of a gum arabic solution (starting concentration $1 \mathrm{mg} / \mathrm{ml}$ ) as a positive control. The prints were allowed to dry and blocked with $5 \%$ of milk powder in phosphate buffered saline solution (PBS/MP). The samples were then probed with the rat anti-AGP monoclonal antibodies (Plant Probes, Leeds, UK) JIM8, JIM13, JIM16, JIM4, LM2, LM14 and MAC207 diluted 10-fold in PBS/MP (Moller et al., 2007). After washing, anti-rat-HRP (diluted 1000-fold) was added in PBS/MP. After an additional wash, antibody-epitope interactions were detected using a luminescent ECL substrate (BioRad) and a Fusion FX.XT-820.EPI/20M system (Vilber Lourmat, France).

Yariv reagent tests. $\beta$-D-glucosyl ( $\beta$ Glc) or $\beta$-D-mannosyl ( $\beta$ Man) Yariv reagents (Biosupplies Pty Ltd, Melbourne, Australia) were added to Provasoli-enriched SCM at final concentrations of $2 \mu \mathrm{g} / \mathrm{ml}$ before carrying out diffusible factor bioassays.

SCM analysis by SDS-PAGE. An initial volume of $200 \mathrm{ml} \mathrm{SCM}$ was concentrated using two Amicon ${ }^{\circledR}$ Ultra-15 $30 \mathrm{kDa}$ centrifugal filters by sequentially centrifuging $15 \mathrm{ml}$ aliquots for $8 \mathrm{~min}$ at $3500 \mathrm{rpm}$. Each of the retentates ( $1.5 \mathrm{ml}$ for each of the two filters) was then washed with $100 \mathrm{ml}$ MilliQ $\mathrm{H}_{2} \mathrm{O}$ by adding batches of $15 \mathrm{ml}$ and centrifuging each time for $8 \mathrm{~min}$ at $3500 \mathrm{rpm}$. The final retentate, a total of $2 \mathrm{ml}$ from the two filters was freeze-dried and redissolved in $10 \mu \mathrm{M}$ MilliQ $\mathrm{H}_{2} \mathrm{O}$ and $2 \mu \mathrm{l}$ of $6 \mathrm{x}$ protein loading buffer $(360 \mathrm{mM}$ Tris-HCl pH 6.8, 45\% Glycerol, 9\% SDS, 9\% DTT, 0.12\% Bromophenol Blue). Twelve microlitres of this sample was heated to $100^{\circ} \mathrm{C}$ for $10 \mathrm{~min}$ before separation by sodium dodecyl sulphate polyacrylamide gel electrophoresis (SDS-PAGE, 12\% w/v; Brunelle and Green 2014) at 120 V. Gels were stained with Coomassie blue for $1 \mathrm{~h}$ then washed three times in $20 \%$ ethanol $/ 10 \%$ acetic acid.

Protein digestion and mass spectrometry analysis. Protein bands were excised from an SDS-PAGE gel for mass spectrometry analysis, which was carried out at the Paris Sud Ouest PAPPSO proteomics core facility (http://papso.inra.fr). Gel pieces were washed three times with $50 \mu 1$ of $10 \%$ formic acid in $40 \%$ ethanol, and $50 \mu \mathrm{l}$ of $50 \mathrm{mM}$ sodium bicarbonate $\left(\mathrm{NH}_{4} \mathrm{HCO}_{3}\right)$ in $50 \%$ acetonitrile (ACN). The gel pieces were incubated in $10 \mathrm{mM}$ dithiothreitol at $56^{\circ} \mathrm{C}$ to reduce any disulphide bridges and the cysteines were alkylated with 50 $\mathrm{mM}$ iodoacetamide. In-gel digestion was carried out overnight at $37^{\circ} \mathrm{C}$ with $100 \mathrm{ng}$ of trypsin in $50 \mathrm{mM}$ sodium bicarbonate. Peptides were extracted with $0.1 \%$ trifluoroacetic acid (TFA) in $40 \%$ ACN, dried in a speed vac and redissolved in $20 \mu 1$ of $0.1 \%$ TFA in $2 \%$ ACN. Four microlitres of this preparation were injected into the LC-MS/MS system.

LC-MS/MS analyses were carried out using an Ultimate 3000 RSLC system (Thermo Scientific) coupled to a LTQ-orbitrap discovery mass spectrometer (Thermo Scientific) by a nanoelectrospray ion source. The protein digest was injected and preconcentrated on a precolumn (Acclaim PepMap C18 particle $5 \mu \mathrm{m}$ size, 5 
mm length, $300 \mu \mathrm{m}$ i.d., Thermo Fisher Scientific) at $20 \mu 1 / \mathrm{min}$ with $0.08 \% \mathrm{TFA}$ in $2 \% \mathrm{ACN}$ for 2 min, followed by a separation on a reverse phase separating column (Acclaim PepMap RSLC nanoViper, C18 particle $2 \mu \mathrm{m}$ size, $150 \mathrm{~mm}$ length, $75 \mu \mathrm{m}$ i.d., Thermo Fisher Scientific). Buffers were $0.1 \%$ formic acid in $98 \%$ water (solvent A) and $0.1 \%$ formic acid in $80 \% \mathrm{ACN}$ (solvent B). The peptides were eluted with a multi-step gradient from $1 \%$ to $35 \%$ of solvent $\mathrm{B}$ for $34.5 \mathrm{~min}$ at $300 \mathrm{nl} / \mathrm{min}$ for a total run of $42 \mathrm{~min}$. MS scans were acquired in a mass range of $300-1400 \mathrm{~m} / \mathrm{z}$ at a resolution of 15000 in the orbitrap analyser. The eight most intense ions were selected for CID MS/MS with a normalised collision energy of 35 in the ion trap.

All MS/MS spectra were searched against a database of deduced proteins based on version 2 of the Ectocarpus genome annotation (https://bioinformatics.psb.ugent.be/orcae/overview/EctsiV2) using the $\mathrm{X}$ !TandemPipeline (version 3.4.3), an open search engine developed by PAPPSO (http://pappso.inra.fr/bioinfo/xtandempipeline/). Precursor mass tolerance was $10 \mathrm{ppm}$ and fragment mass tolerance was 0.5 Da. Data was filtered using the following criteria: a peptide E-value of $<0.01$, a protein Evalue of $<10 \mathrm{e}-4$ and a minimum of two identified peptides per protein.

\section{RESULTS}

Rapidly released uni-spores are more responsive to the sporophyte-inducing diffusible factor. Arun et al. (2013) demonstrated that Ectocarpus sporophytes secrete a diffusible factor that induces uni-spores to switch from the gametophyte to the sporophyte developmental program. With the objective of further characterising this diffusible factor, we first aimed to determine optimal conditions for its production and assay. The physiological state of an sporophyte can influence unilocular sporangium production and function, leading to developmental abnormalities of the sporangium and often delayed or dysfunctional release of uni-spores. To assess the effect of uni-spore quality on detection of the diffusible factor, we compared batches of unilocular sporangia that had released after 12-24 h, 24-48 h or $>48 \mathrm{~h}$ of incubation in SCM to determine whether the time taken to release the spores influenced the proportion of uni-spores that were converted to the sporophyte generation (Fig. 1A). This analysis indicated that rapidly released uni-spores (i.e. within $24 \mathrm{~h}$ ) were more sensitive to the diffusible factor than uni-spores whose release had been delayed (i.e. taking $>48 \mathrm{~h}$;

Wilcoxon-Mann-Whitney test, $W=1614.5, p$-value $=0.0313$ ). Based on this observation, whenever possible, subsequent experiments were carried out with uni-spores that had been released within $48 \mathrm{~h}$ of transfer of the micro-dissected unilocular sporangia to the test conditions.

The sporophyte-inducing diffusible factor is stable when stored at $4^{\circ} \mathrm{C}$ or at $-20^{\circ} \mathrm{C}$. To test the stability of the sporophyte-inducing factor, SCM was stored at either $4{ }^{\circ} \mathrm{C}$ or at $-20^{\circ} \mathrm{C}$ and its activity tested after different time periods (Fig. 1B). The results of this analysis indicated that the factor was stable for at least eight weeks 
at $4^{\circ} \mathrm{C}$. Similarly, storage at $-20^{\circ}$ for one to five weeks did not result in a decrease in the activity of the diffusible factor (Fig. 1C). We noted that SCM activity increased after storage for more than five weeks at $4^{\circ} \mathrm{C}$ but no increase in activity was not observed when the medium was stored at $-20^{\circ} \mathrm{C}$ for the same period of time.

Effect of sporophyte culture conditions on production of the sporophyte-inducing diffusible factor. We next tested whether the conditions under which the sporophyte material was cultivated influenced production of the diffusible factor. To test whether diffusible factor production was influenced by the length of time the sporophyte material was maintained in culture, Provasoli-enriched natural seawater (PES) was inoculated with gametes and the resulting partheno-sporophytes were cultivated for different times under standard conditions. The SCM samples were removed after four, six, eight and ten weeks and assayed for diffusible factor activity (Fig. 1D). This experiment indicated that SCM contained the highest activities after six to eight weeks of culture, with the activity diminishing in older cultures.

To test the effect of light intensity, PES was inoculated with gametes and the resulting partheno-sporophytes grown either under low (2-3 $\mu$ mol photons $\left./ \mathrm{m}^{2} \cdot \mathrm{s}\right)$, medium (15-16 $\mu$ mol photons $\left./ \mathrm{m}^{2} \cdot \mathrm{s}\right)$ or high light $(25-30$ $\mu \mathrm{mol}$ photons $/ \mathrm{m}^{2} \cdot \mathrm{s}$ ) conditions. SCM was collected after four weeks of culture and assayed for the diffusible factor (Fig. 1E). There were no significant differences between the detected levels of diffusible factor produced by the cultures that were grown under the three light conditions (Wilcoxon-Mann-Whitney test, $W$ $=1461,785.5$ and 571.5, $p$-values $=0.6847,0.0740$ and 0.2480 for low light versus normal light, low light versus high light and normal light versus high light, respectively).

Based on these experiments, cultivation times of five to six weeks under low light conditions (to limit the growth rate of the cultures) were used to produce SCM for subsequent experiments.

The diffusible factor is a large molecule. As a first step towards investigating the biochemical nature of the diffusible factor, we used ultrafiltration to estimate its molecular size. SCM was filtered through an ÄKTA ${ }^{\mathrm{TM}}$ flux ultrafiltration system using filters with different molecular size cut-offs to prepare different size fractions (Fig. 2A). Bioassay testing of the different size fractions indicated that the diffusible factor had a molecular size of greater than $50 \mathrm{kDa}$ and that at least part of the activity had a molecular size of less than $100 \mathrm{kDa}$ (Fig. 2B).

Mass spectrometry analysis of proteins in concentrated SCM. To further characterise the high molecular weight fraction, $200 \mathrm{ml}$ of SCM was processed with a Falcon filter system to concentrate $>30 \mathrm{kDa}$ components. Coomassie blue staining of the concentrated SCM sample after separation on SDS-PAGE (Fig. $3 \mathrm{~A}$ ) revealed several high molecular weight bands of greater than $50 \mathrm{kDa}$ (i.e. in the active size range 
determined by ultrafiltration experiments, Fig. 2B). Liquid chromatography coupled to mass spectrometry (LC-MS/MS) analysis of the SDS-PAGE bands identified peptides corresponding to 36 different proteins (Table 1). Most of the proteins detected were predicted to be secreted proteins based on the presence of a putative signal peptide and several of the proteins could potentially play a role in cell to cell signalling. For example AGPs have important signalling roles in land plants and the list included a mannuronan C5epimerase (locusID Ec-20_004700, Fig. 3B) that had been reported to contain three chimeric AGP backbone motifs (Hervé et al. 2016).

\section{The sporophyte-inducing diffusible factor is resistant to autoclaving and proteinase K treatment. To} characterise the diffusible factor further, we determined whether it was stable when treated with high temperature or subjected to protease digestion. SCM was either autoclaved or digested by incubation at $37^{\circ} \mathrm{C}$ in the presence of $100 \mu \mathrm{g} / \mathrm{ml}$ proteinase $\mathrm{K}$ followed by autoclaving to denature the enzyme. Fig. 4 shows that the diffusible factor was resistant to both autoclaving and proteinase K treatment. Surprisingly, the activity of the factor significantly increased following proteinase $\mathrm{K}$ treatment (Wilcoxon-Mann-Whitney test, $W=45.5$, $p$-value $=0.03785)$.

This result of this experiment suggested that the diffusible factor may not be a protein but note that alternative interpretations of these results are possible. For example, the factor could be a complex molecule such as a glycoprotein, with the protein part of the molecule being either inaccessible to proteinase $\mathrm{K}$ or unnecessary for the factor's activity. This interpretation would be consistent with the diffusible factor corresponding to an AGP for example (based on the detection of Ec-20_004700 in the SCM). We therefore carried out some additional experiments aimed at further exploring the possibility that the SCM contains active AGP-like molecules.

\section{Detection of AGP glycan epitopes in sporophyte-conditioned medium. Anti-AGP antibodies were used to} assay for the presence of AGP-like proteins in SCM. Fig. 5 shows that AGP epitopes were detected in the high molecular weight SCM fraction after it had been concentrated by ultrafiltration. The strongest signals were obtained with the JIM13, JIM4 and MAC207 antibodies, but JIM16, LM14 and JIM8 also weakly detected epitopes. This experiment, therefore, confirmed that sporophytes secrete AGP-like molecules into the culture medium.

Decreased bio-activity of SCM in the presence of an AGP-reactive Yariv reagent. To determine whether AGP-like molecules have a role in the sporophyte-inducing activity of SCM, Yariv reagents were added to sporophyte-conditioned medium before testing for bioactivity. $\beta$-D-glucosyl and $\beta$-D-galactosyl Yariv reagents have been shown to react specifically with plant AGPs (Gane et al. 1995, Paulsen et al. 2014) and 
inhibit their functions (Johnson et al. 2003, Tan et al. 2012, Hervé et al. 2016). Fig. 6 shows that addition of the $\beta$ Glc Yariv reagent to SCM resulted in a significant decrease in activity (Wilcoxon-Mann-Whitney test, $W=115, p$-value $=0.0369)$ in the uni-spore bioassay, whereas addition of an inactive analogue, $\beta$ Man Yariv reagent, as a control did not. The results of this experiment were consistent with the diffusible factor being an AGP.

\section{DISCUSSION}

Genetic experiments have shown that the switch from the gametophyte to the sporophyte generation in Ectocarpus is controlled by two TALE HD TFs, OUROBOROS and SAMSARA (Coelho et al. 2011, Arun et al. 2019), but this switch can also be influenced by a non-cell autonomous, sporophyte-inducing factor that is secreted into the medium by the sporophyte generation (Arun et al. 2013). The experiments carried out here were aimed at further characterising this diffusible factor. We show that light intensity does not significantly influence production of the diffusible factor but at lower light intensities the algae grow more slowly allowing them to be maintained at higher densities for longer periods of time. Ectocarpus parthenosporophytes normally become sexually mature after three to four weeks under normal light and, therefore, cultures cannot be maintained for long periods under these conditions. We also showed that SCM did not lose its activity when stored for 8 weeks at either $4^{\circ} \mathrm{C}$ or $-20^{\circ} \mathrm{C}$.

Further characterisation of the SCM indicated that the sporophyte-inducing factor was resistant to heat $\left(121^{\circ} \mathrm{C}\right.$ for $\left.30 \mathrm{~min}\right)$ and proteinase $\mathrm{K}$ treatment and that the factor was a large molecular weight molecule, greater than $50 \mathrm{kDa}$ in size. Mass spectrometry analysis identified 36 different proteins in concentrated SCM, including a mannuronan C5-epimerase (locusID Ec-20_004700) that has been reported to contain chimeric AGP backbone motifs (Hervé et al. 2016). Brown algal cell walls play an important role in conferring resistance to mechanical stress and protection from predators (Popper et al. 2011). They are mainly composed of alginates and sulphated fucans and therefore differ markedly in their composition from the cell walls of land plants (Hervé et al. 2016). Mannuronan C5-epimerase acts on alginate, altering its mechanical properties by converting $\beta$-D-mannuronate to its epimer $\beta$-L-guluronate (Nyvall et al. 2003, Fischl et al. 2016). The mannuronan C5-epimerase protein Ec-20_004700 is predicted to contain wall sensing component (WSC) domains, in addition to its catalytic domain. WSC domains have been associated with cell wall sensing (Ohsawa et al. 2017, Oide et al. 2019) and resistance to various stress conditions in fungi (Lodder et al. 1999, Lommel et al. 2004, Dupres et al. 2009). Recent studies indicate that fungal WSC proteins might contribute to protein anchoring and colonization of plant hosts through their ability to bind a variety of cell wall polysaccharides from plants and fungi including $\beta$-1,3-glucans, xylans and chitin (Oide et al. 2019, Wawra et al. 2019). The WSC domain family is one of the largest protein domain families in brown algae, with 444 members in Ectocarpus sp. strain Ec32 (Dittami et al. 2020). Three of the 28 mannuronan C5epimerase enzymes in Ectocarpus are predicted to possess WSC domains and, while their biochemical 
function has not been yet elucidated, these motifs may act as cell wall-binding domains, possibly targeting alginate (Michel et al. 2010).

One particularly interesting feature of the mannuronan C5-epimerase that was detected in ultrafiltrated SCM (encoded by the gene with LocusID Ec-20_004700) was the presence of three AGP backbone motifs. AGPs are large molecular weight glycoproteins (from 50 to more than $200 \mathrm{kDa}$ ) that were initially detected in land plant cell surfaces. Together with extensins and proline-rich proteins, AGPs belong to the group of hydroxyproline-rich-glycoproteins. AGPs are structurally characterized by a large carbohydrate moiety that accounts for $90-98 \%(\mathrm{w} / \mathrm{w})$ of the molecule. Land plant AGPs consist predominantly of $\beta-1,3$-galactan main chains with $\beta$-1,6-galactan side chains, to which primarily arabinose and some other auxiliary sugar residues, such as rhamnose and glucuronic acid, are attached at their termini (Tan et al. 2012). This carbohydrate moiety is covalently linked via hydroxyproline to a relatively small protein backbone. AGPs have been shown to play crucial roles during development and reproduction in the land plant lineage (Hancock et al. 2005, Fu et al. 2007, Seifert and Roberts 2007). Developmental switches that appear to be influenced by AGPs in land plants include, for example, the acquisition of embryogenic capacity in Daucus carota (Kreuger and van Holst 1993, van Hengel et al. 2001), the role of the AGP-like protein xylogen in xylem formation in Zinnia and Arabidopsis (Motose et al. 2004) and the role of AGP18 in the selection of viable megaspores in Arabidopsis (Demesa-Arévalo and Vielle-Calzada 2013). The phenotype associated with AGP18 is particularly interesting as this glycoprotein acts at the transition from the sporophyte to the gametophyte generation and loss of AGP18 leads to an arrest of gametogenesis (Acosta-García and VielleCalzada 2004). AGPs have also been shown to act as signal molecules during fertilisation. For example, tobacco TTS, which is produced by the stylar transmitting tissue, appears to act as a signalling factor to guide pollen tube growth (Cheung et al. 1995) and, in the land plant Torenia fournieri, ovular methylglucuronosyl arabinogalactan (AMOR) induces competency of the pollen tube to respond to ovular attractant peptides (Mizukami et al. 2016, Jiao et al. 2017).

In contrast to the situation for land plants, evidence for the presence of chimeric AGPs in brown algae has only been reported recently. Hervé et al. (2016) identified multiple genes in the Ectocarpus genome that were predicted to encode AGP-like core proteins. It is unknown if brown algal AGPs share conserved structural features with AGPs from land plants, however anti-AGP antibodies detect glycan epitopes in a variety of brown algae. The Hervé et al. (Hervé et al. 2016) study also presented evidence that AGP-like proteins are developmentally regulated during Fucus development and that developmental abnormalities occur if the action of the Fucus proteins is inhibited by the addition of AGP-reactive Yariv reagents. In the current study, anti-AGP antibodies detected AGP glycan epitopes in SCM and addition of the Yariv reagent $\beta$-glucosyl to SCM led to an inhibition of its sporophyte-inducing activity. These observations suggest the interesting possibility that the sporophyte-inducing factor might be an AGP-like molecule. The lack of susceptibility of the sporophyte-inducing factor to proteinase $\mathrm{K}$ and heat treatment could be 
interpreted as an argument against the factor corresponding to a protein but note that plant AGPs with similar heat and protease tolerances have been described. For example, xylogen has been shown to be heat resistant, although its activity is eliminated by proteases (Motose et al. 2001). AMOR was found to be both heat stable $\left(100^{\circ} \mathrm{C}\right.$ for $\left.10 \mathrm{~min}\right)$ and maintained its activity following treatment with proteinase $\mathrm{K}$. For the latter, a disaccharide, methyl-glucuronosyl galactose (4-Me-GlcA- $\beta-(1 / 6)-G a l)$, was synthesised and shown to exhibit AMOR activity, suggesting that the protein moiety may not be important for the observed biological activity (Mizukami et al. 2016). By analogy, it is therefore possible that the active moiety of the Ectocarpus sporophyte-inducing factor is a saccharide molecule. Interestingly, SCM activity increased after storage for more than five weeks at $4{ }^{\circ} \mathrm{C}$ (Fig. 1B) but no increase was observed when the medium was stored at $-20^{\circ} \mathrm{C}$ for the same period of time (Fig. 1C). One possible interpretation of this observation might be that degradation of the diffusible factor led to the production of a more active degradation product such as a saccharide molecule.

In conclusion, this study has optimized conditions for the production of the sporophyte-inducing factor and has provided some initial information about its molecular nature that will be important for future attempts to purify the factor. Several different approaches provided evidence that the factor may be an AGP or an AGPlike molecule. Future work will be aimed at characterising the exact molecular nature of the factor and at investigating how the factor functions to induce the sporophyte program. On a broader scale, characterisation of the Ectocarpus factor may provide a starting point for the characterisation of analogous factors in other eukaryotic lineages. For example, moss sporophytes have been reported to produce a diffusible factor that induces apogamous sporophyte formation (Bauer, 1959) but the nature of this factor has not been investigated.

\section{ACKNOWLEDGEMENTS}

This work was supported by the Centre National de la Recherche Scientifique, the European Research Council (grant agreement 638240) and Sorbonne University. Support was also provided by the French National Research Agency via the investment expenditure programme Idealg (ANR-10-BTBR-04-02). HY was supported by a grant from the Chinese Scholarship Council (grant number 201608310119).

\section{AUTHOR CONTRIBUTIONS}

JMC and SMC conceived the study. HY carried out the experiments with input from DS for culture and bioassays and from MJ, CH and PP for biochemical and immunological analyses. LOC carried out the mass spectrometry analysis. HY analysed the data with input from DS, MJ, CH, PP, HY, SMC and JMC. HY, SMC and JMC wrote the first draft of the manuscript. All authors contributed to the final version. JMC and SMC contributed equally. 


\section{CONFLICT OF INTEREST}

400 The authors have no conflict of interest.

\section{References}

403

Acosta-García, G. \& Vielle-Calzada, J.-P. 2004. A classical arabinogalactan protein is essential for the initiation of female gametogenesis in Arabidopsis. Plant Cell. 16:2614-28.

Arun, A., Coelho, S.M., Peters, A.F., Bourdareau, S., Pérès, L., Scornet, D., Strittmatter, M. et al. 2019. Convergent recruitment of TALE homeodomain life cycle regulators to direct sporophyte development in land plants and brown algae. eLife. 8:e43101.

Arun, A., Peters, N.T., Scornet, D., Peters, A.F., Cock, J.M. \& Coelho, S.M. 2013. Non-cell autonomous regulation of life cycle transitions in the model brown alga Ectocarpus. New Phytol. 197:503-10.

Bothwell, J.H., Marie, D., Peters, A.F., Cock, J.M. \& Coelho, S.M. 2010. Role of endoreduplication and apomeiosis during parthenogenetic reproduction in the model brown alga Ectocarpus. New Phytol. 188:111-21.

Brunelle, J. \& Green, R. 2014. One-dimensional SDS-polyacrylamide gel electrophoresis (1D SDS-PAGE). In Methods in Enzymology. Elsevier, pp. 151-9.

Cheung, A.Y., Wang, H. \& Wu, H.M. 1995. A floral transmitting tissue-specific glycoprotein attracts pollen tubes and stimulates their growth. Cell. 82:383-93.

Cock, J.M., Godfroy, O., Macaisne, N., Peters, A.F. \& Coelho, S.M. 2014. Evolution and regulation of complex life cycles: a brown algal perspective. Curr Opin Plant Biol. 17:1-6.

Coelho, S. \& Cock, J. 2020. Brown algal model organisms. Ann Rev Genet. in press.

Coelho, S., Peters, A.F., Charrier, B., Destombe, C., Valero, M. \& Cock, J. 2007. Complex life cycles of multicellular eukaryotes: new approaches based on the use of model organisms. Gene. 406:152-70.

Coelho, S.M., Godfroy, O., Arun, A., Le Corguillé, G., Peters, A.F. \& Cock, J.M. 2011. OUROBOROS is a master regulator of the gametophyte to sporophyte life cycle transition in the brown alga Ectocarpus. Proc Natl Acad Sci USA. 108:11518-23.

Coelho, S.M., Scornet, D., Rousvoal, S., Peters, N.T., Dartevelle, L., Peters, A.F. \& Cock, J.M. 2012. How to cultivate Ectocarpus. Cold Spring Harb Protoc. 2012:258-61.

Demesa-Arévalo, E. \& Vielle-Calzada, J.-P. 2013. The classical arabinogalactan protein AGP18 mediates megaspore selection in Arabidopsis. Plant Cell. 25:1274-87.

Dittami, S.M., Corre, E., Brillet-Guéguen, L., Lipinska, A.P., Pontoizeau, N., Aite, M., Avia, K. et al. 2020. The genome of Ectocarpus subulatus - A highly stress-tolerant brown alga. Mar. Genomics. 100740.

Dupres, V., Alsteens, D., Wilk, S., Hansen, B., Heinisch, J.J. \& Dufrêne, Y.F. 2009. The yeast Wsc1 cell surface sensor behaves like a nanospring in vivo. Nat. Chem. Biol. 5:857-62.

Fischl, R., Bertelsen, K., Gaillard, F., Coelho, S., Michel, G., Klinger, M., Boyen, C. et al. 2016. The cell-wall active mannuronan $\mathrm{C} 5$-epimerases in the model brown alga Ectocarpus: From gene context to recombinant protein. Glycobiology. 26:973-83.

Fu, H., Yadav, M.P. \& Nothnagel, E.A. 2007. Physcomitrella patens arabinogalactan proteins contain abundant terminal 3-O-methyl-L: -rhamnosyl residues not found in angiosperms. Planta. 226:151124. 
Gane, A.M., Craik, D., Munro, S.L., Howlett, G.J., Clarke, A.E. \& Bacic, A. 1995. Structural analysis of the carbohydrate moiety of arabinogalactan-proteins from stigmas and styles of Nicotiana alata. Carbohydr. Res. 277:67-85.

Hancock, C.N., Kent, L. \& McClure, B.A. 2005. The stylar $120 \mathrm{kDa}$ glycoprotein is required for S-specific pollen rejection in Nicotiana. Plant J. Cell Mol. Biol. 43:716-23.

Hervé, C., Siméon, A., Jam, M., Cassin, A., Johnson, K.L., Salmeán, A.A., Willats, W.G.T. et al. 2016. Arabinogalactan proteins have deep roots in eukaryotes: identification of genes and epitopes in brown algae and their role in Fucus serratus embryo development. New Phytol. 209:1428-41.

Jiao, J., Mizukami, A.G., Sankaranarayanan, S., Yamguchi, J., Itami, K. \& Higashiyawma, T. 2017. StructureActivity Relation of AMOR Sugar Molecule That Activates Pollen-Tubes for Ovular Guidance. Plant Physiol. 173:354-63.

Johnson, K.L., Jones, B.J., Bacic, A. \& Schultz, C.J. 2003. The fasciclin-like arabinogalactan proteins of Arabidopsis. A multigene family of putative cell adhesion molecules. Plant Physiol. 133:1911-25.

Kreuger, M. \& van Holst, G.-J. 1993. Arabinogalactan proteins are essential in somatic embryogenesis of Daucus carota L. Planta. 189:243-8.

Lodder, A.L., Lee, T.K. \& Ballester, R. 1999. Characterization of the Wsc1 protein, a putative receptor in the stress response of Saccharomyces cerevisiae. Genetics. 152:1487-99.

Lommel, M., Bagnat, M. \& Strahl, S. 2004. Aberrant processing of the WSC family and Mid2p cell surface sensors results in cell death of Saccharomyces cerevisiae O-mannosylation mutants. Mol. Cell. Biol. 24:46-57.

Michel, G., Tonon, T., Scornet, D., Cock, J.M. \& Kloareg, B. 2010. The cell wall polysaccharide metabolism of the brown alga Ectocarpus siliculosus. Insights into the evolution of extracellular matrix polysaccharides in Eukaryotes. New Phytol. 188:82-97.

Mizukami, A.G., Inatsugi, R., Jiao, J., Kotake, T., Kuwata, K., Ootani, K., Okuda, S. et al. 2016. The AMOR Arabinogalactan Sugar Chain Induces Pollen-Tube Competency to Respond to Ovular Guidance. Curr. Biol. CB. 26:1091-7.

Motose, H., Sugiyama, M. \& Fukuda, H. 2001. An arabinogalactan protein(s) is a key component of a fraction that mediates local intercellular communication involved in tracheary element differentiation of zinnia mesophyll cells. Plant Cell Physiol. 42:129-37.

Motose, H., Sugiyama, M. \& Fukuda, H. 2004. A proteoglycan mediates inductive interaction during plant vascular development. Nature. 429:873-8.

Müller, D.G. 1967. Generationswechsel, Kernphasenwechsel und Sexualität der Braunalge Ectocarpus siliculosus im Kulturversuch. Planta. 75:39-54.

Nyvall, P., Corre, E., Boisset, C., Barbeyron, T., Rousvoal, S., Scornet, D., Kloareg, B. et al. 2003. Characterization of mannuronan C-5-epimerase genes from the brown alga Laminaria digitata. Plant Physiol. 133:726-35.

Ohsawa, S., Yurimoto, H. \& Sakai, Y. 2017. Novel function of Wsc proteins as a methanol-sensing machinery in the yeast Pichia pastoris. Mol. Microbiol. 104:349-63.

Oide, S., Tanaka, Y., Watanabe, A. \& Inui, M. 2019. Carbohydrate-binding property of a cell wall integrity and stress response component (WSC) domain of an alcohol oxidase from the rice blast pathogen Pyricularia oryzae. Enzyme Microb. Technol. 125:13-20.

Paulsen, B.S., Craik, D.J., Dunstan, D.E., Stone, B.A. \& Bacic, A. 2014. The Yariv reagent: behaviour in different solvents and interaction with a gum arabic arabinogalactan-protein. Carbohydr. Polym. 106:460-8. 
Peters, A.F., Marie, D., Scornet, D., Kloareg, B. \& Cock, J.M. 2004. Proposal of Ectocarpus siliculosus (Ectocarpales, Phaeophyceae) as a model organism for brown algal genetics and genomics. $J$ Phycol. 40:1079-88.

Peters, A.F., Scornet, D., Ratin, M., Charrier, B., Monnier, A., Merrien, Y., Corre, E. et al. 2008. Life-cyclegeneration-specific developmental processes are modified in the immediate upright mutant of the brown alga Ectocarpus siliculosus. Development. 135:1503-12.

Popper, Z.A., Michel, G., Hervé, C., Domozych, D.S., Willats, W.G.T., Tuohy, M.G., Kloareg, B. et al. 2011. Evolution and diversity of plant cell walls: from algae to flowering plants. Ann Rev Pl Biol. 62:56790.

Seifert, G.J. \& Roberts, K. 2007. The biology of arabinogalactan proteins. Annu. Rev. Plant Biol. 58:137-61.

Tan, L., Showalter, A.M., Egelund, J., Hernandez-Sanchez, A., Doblin, M.S. \& Bacic, A. 2012. Arabinogalactan-proteins and the research challenges for these enigmatic plant cell surface proteoglycans. Front. Plant Sci. 3:140.

van Hengel, A.J., Tadesse, Z., Immerzeel, P., Schols, H., van Kammen, A. \& de Vries, S.C. 2001. Nacetylglucosamine and glucosamine-containing arabinogalactan proteins control somatic embryogenesis. Plant Physiol. 125:1880-90.

Wawra, S., Fesel, P., Widmer, H., Neumann, U., Lahrmann, U., Becker, S., Hehemann, J.-H. et al. 2019. FGB1 and WSC 3 are in planta-induced $\beta$-glucan-binding fungal lectins with different functions. New Phytol. 222:1493-506.

Yao, H., Scornet, D., Badis, Y., Peters, A.F., Jam, M., Hervé, C., Potin, P. et al. 2020. Production and Bioassay of a Diffusible Factor that Induces Gametophyte-to-Sporophyte Developmental Reprogramming in the Brown Alga Ectocarpus. Bio-Protoc. 10:e3753-e3753. 
508 Table 1. Proteins detected in concentrated sporophyte-conditioned medium following SDS-PAGE, excision 509 of bands $>50 \mathrm{kDa}$ and mass spectrometry. SP, signal peptide; TM, transmembrane domain; WSC, cell-wall 510 integrity and stress-response component 1 domain; MC5E, mannuronan C-5-epimerase; AGP, 511 arabinogalactan protein; $\mathrm{G} / \mathrm{SdH}$, glucose/sorbosone dehydrogenase; $\mathrm{PLF} / \mathrm{V}$, pectin lyase fold/virulence 512 factor; PS8/S53, petidase S8/S53; HIP, high-CO2 inducible periplasmic; PKinase, protein kinase; RCC1, 513 regulator of chromosome condensation; SBBP, six-bladed beta-propeller, TolB-like; Gal, galactose-binding; 514 AP, alkaline-phosphatase-like; SGNH, SGNH hydrolase-type esterase; HLRR, hypothetical leucine-rich 515 repeat; vWA, von Willebrand factor type A; FA58C, Coagulation factor 5/8 C-terminal type domain; HP, 516 Haem peroxidase; CA, carbonic anhydrase; GH114, N-terminal glycosyl-hydrolase-114-associated domain.

\begin{tabular}{|c|c|c|c|}
\hline Description & Locus ID & Domains & $\begin{array}{l}\text { Major } \\
\text { Component }\end{array}$ \\
\hline \multirow{8}{*}{$\begin{array}{l}\text { Mannuronan C-5-epimerases } \\
\text { (short name indicated) }\end{array}$} & $\begin{array}{l}\text { Ec-20_004700 } \\
\text { (MEP4) }\end{array}$ & SP, 2xWSC, MC5E, AGP & No \\
\hline & $\begin{array}{l}\text { Ec-00_006370 } \\
\text { (MEP5) }\end{array}$ & SP, MC5E & Yes \\
\hline & $\begin{array}{l}\text { Ec-00_006380 } \\
\text { (MEP6) }\end{array}$ & SP, MC5E & Yes \\
\hline & $\begin{array}{l}\text { Ec-11_000400 } \\
\text { (MEP2) }\end{array}$ & SP, MC5E & Yes \\
\hline & $\begin{array}{l}\text { Ec-27_006700 } \\
\text { (MEP28) }\end{array}$ & SP, MC5E & Yes \\
\hline & $\begin{array}{l}\text { Ec-18_000130 } \\
\text { (MEP7) }\end{array}$ & MC5E & Yes \\
\hline & $\begin{array}{l}\text { Ec-00_010800 } \\
\text { (MEP13) }\end{array}$ & TM, 2xWSC, MC5E & Yes \\
\hline & $\begin{array}{l}\text { Ec-18_000150 } \\
\text { (MEP8) }\end{array}$ & SP, MC5E & No \\
\hline WSC domain protein & Ec-17_000970 & SP, WSC & Yes \\
\hline \multirow{3}{*}{$\begin{array}{l}\text { Glucose/Sorbosone dehydrogenase and } \\
\text { WSC domain protein }\end{array}$} & Ec-00_007780 & $\mathrm{SP}, \mathrm{G} / \mathrm{SdH}, 5 \mathrm{xWSC}$ & Yes \\
\hline & Ec-09_000520 & $\mathrm{SP}, \mathrm{G} / \mathrm{SdH}, \mathrm{WSC}$ & Yes \\
\hline & Ec-13_003060 & $\mathrm{SP}, \mathrm{G} / \mathrm{SdH}, 3 \mathrm{xWSC}$ & No \\
\hline $\begin{array}{l}\text { High- } \mathrm{CO}_{2} \text { inducible periplasmic domain } \\
\text { protein }\end{array}$ & Ec-26_006220 & SP, HIP & Yes \\
\hline \multirow{2}{*}{ Pectin lyase fold proteins } & Ec-03_002910 & $\mathrm{SP}, \mathrm{PLF} / \mathrm{V}$ & No \\
\hline & Ec-22_003520 & SP, PLF/V & Yes \\
\hline $\begin{array}{l}\text { Seven-bladed beta-propeller domain receptor } \\
\text { kinase }\end{array}$ & Ec-22_003740 & SP, RCC1, TM, PKinase & Yes \\
\hline \multirow{2}{*}{ TolB-like six-bladed beta-propeller proteins } & Ec-15_001700 & SP, SBBP & Yes \\
\hline & Ec-02_001340 & SP, SBBP & No \\
\hline
\end{tabular}




\begin{tabular}{|c|c|c|c|}
\hline \multirow{4}{*}{ Galactose-binding domain-like proteins } & Ec-21_001340 & SP, 3xGal, PLF/V & No \\
\hline & Ec-21_001320 & $\mathrm{SP}, \mathrm{Gal}, \mathrm{PLF} / \mathrm{V}$ & No \\
\hline & Ec-21_001360 & SP, 3xGal, PLF/V & Yes \\
\hline & Ec-21_001350 & $\mathrm{SP}, 2 \mathrm{xGal}, \mathrm{PLF} / \mathrm{V}$ & Yes \\
\hline Seven-bladed beta-propeller domain protein & Ec-16_004480 & SP, RCC1, TM & Yes \\
\hline \multirow{2}{*}{ Secreted protein similar to EsV-1-163 } & Ec-26_002660 & SP & No \\
\hline & Ec-26_005190 & SP & No \\
\hline asn/thr-rich large protein family protein & Ec-02_004700 & SP & No \\
\hline Secreted alkaline phosphatase & Ec-01_007880 & SP, AP & Yes \\
\hline KP-43 peptidase & Ec-06_007900 & PS8/S53, Gal & No \\
\hline SGNH hydrolase-type esterase domain & Ec-09_000420 & SP, SGNH & No \\
\hline Hypothetical leucine rich repeat protein & Ec-09_004400 & SP, Gal, FA58C, LRR & No \\
\hline $\begin{array}{l}\text { Von Willebrand factor type A domain } \\
\text { protein }\end{array}$ & Ec-21_003770 & vWA & No \\
\hline Catalase (imm downregulated 7) & Ec-26_000310 & SP, HP & Yes \\
\hline FAS1 domain protein & Ec-27_005070 & FAS1, TM & Yes \\
\hline carbonic anhydrase alpha type & Ec-27_005680 & $\mathrm{SP}, \mathrm{CA}$ & No \\
\hline conserved unknown protein & Ec-05_001620 & SP & Yes \\
\hline GH114 glycosyl-hydrolase & Ec-28_003870 & GH114 & Yes \\
\hline
\end{tabular}


A

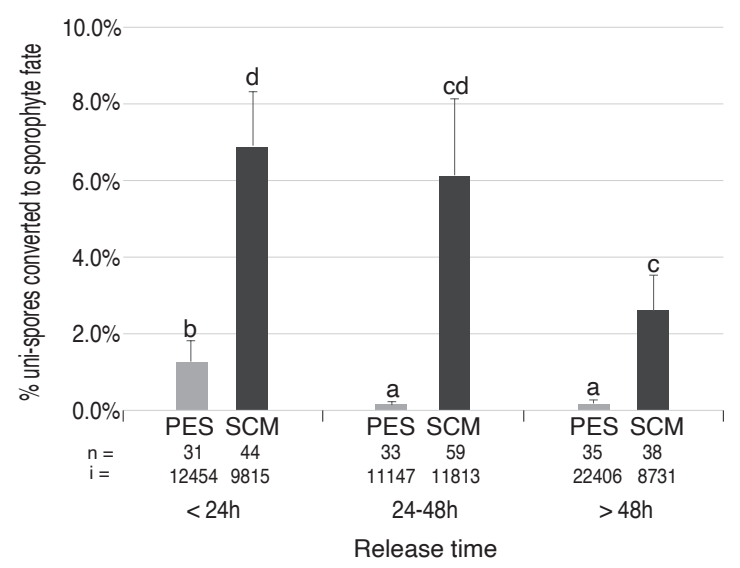

B

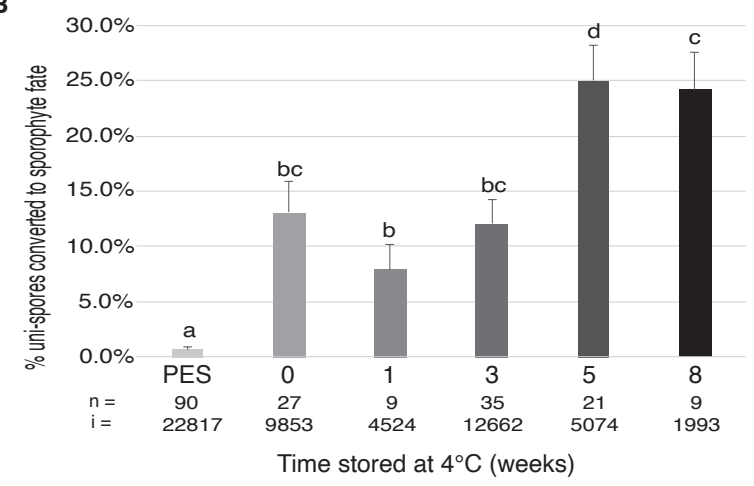

C

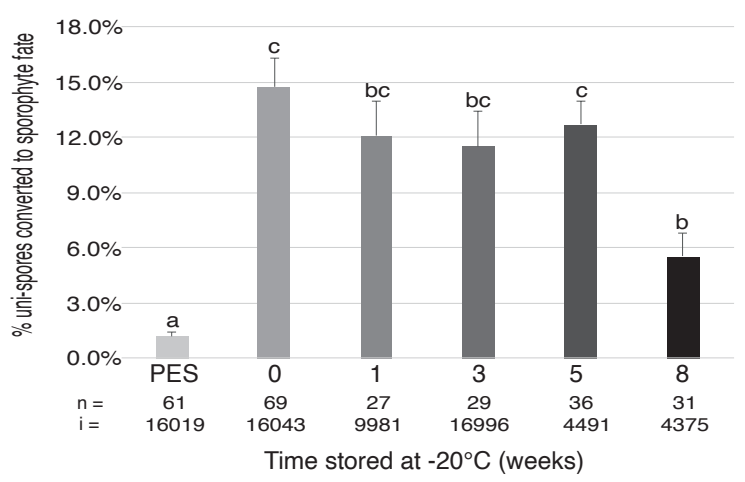

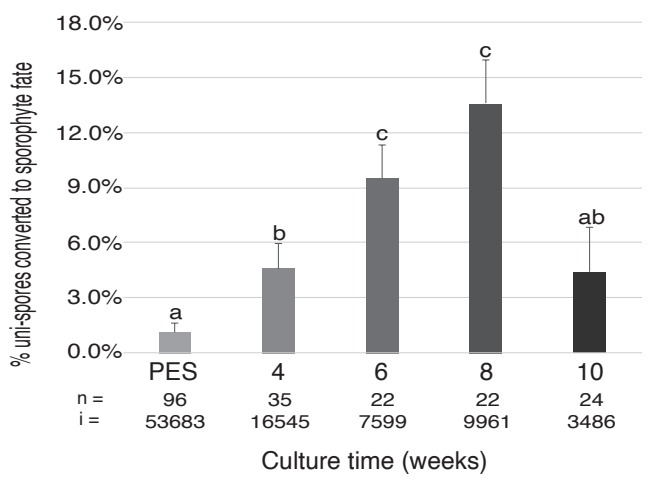

$\mathbf{E}$

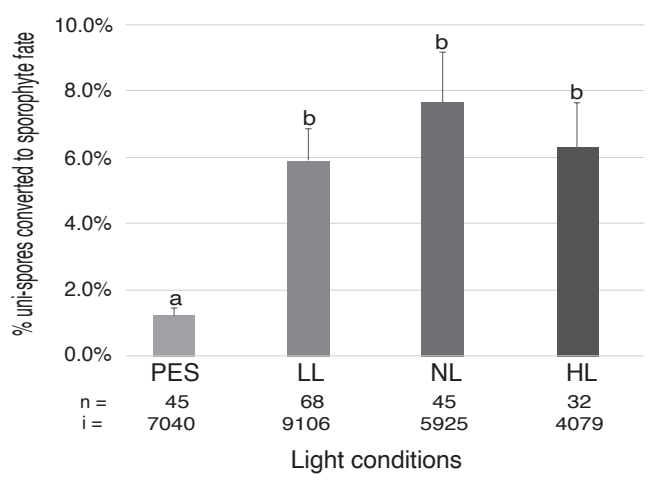

523 Fig. 1. Effect of different parameters on the activity of the diffusible factor. (A) Effect of unilocular 524 sporangium release time on uni-spore susceptibility to the diffusible sporophyte-inducing factor. Percent of germlings that exhibited sporophyte morphology following the release of uni-spores from unilocular sporangia $12-24 \mathrm{~h}, 24-48 \mathrm{~h}$ or $>48 \mathrm{~h}$ after dissection and transfer to either SCM or to PES as a negative control. (B,C) The sporophyte-inducing factor is stable when SCM is stored at $4{ }^{\circ} \mathrm{C}$ or $-20^{\circ} \mathrm{C}$. (B) Bioassay 
528 activity after storage at $4{ }^{\circ} \mathrm{C}$. (C) Bioassay activity after storage at $-20^{\circ} \mathrm{C}$. (D,E) Effect of sporophyte culture 529 conditions on production of the sporophyte-inducing diffusible factor. (D) Effect of time in culture, (E)

530 Effect of light intensity. Error bars indicate standard error of the mean, letters above bars indicate significant 531 differences (Wilcoxon-Mann-Whitney test, $p$-value $<0.05$; see table S1 for details of statistical tests). PES, 532 Provasoli-enriched natural seawater; LL, low light; NL, normal light; HL, high light; n, number of replicates; 533 i, number of individual germlings counted. 
A

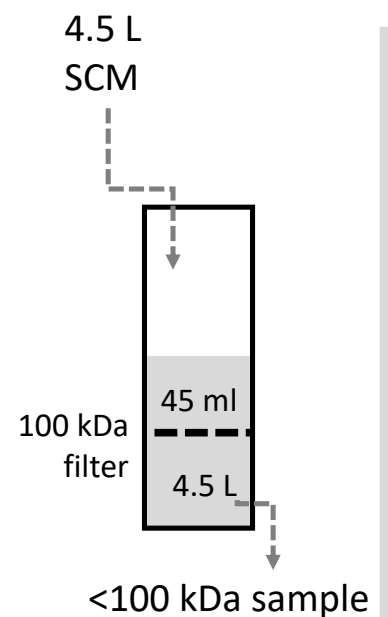

(1x)

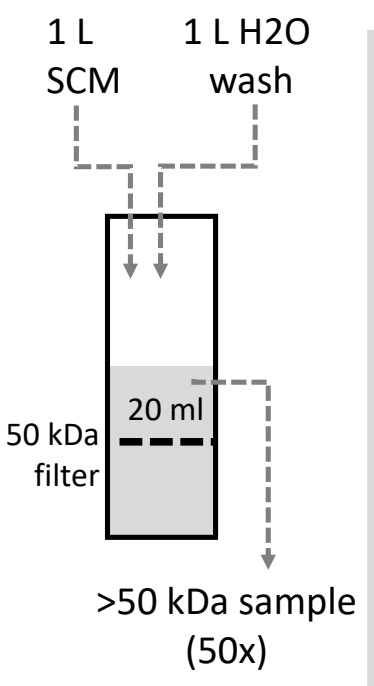

$1 \mathrm{~L}$

SCM<smiles>[AsH2]=[AsH2]</smiles>

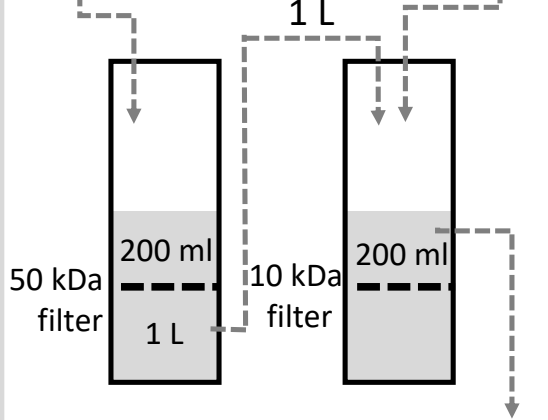

10-50 kDa sample

(5x)

B

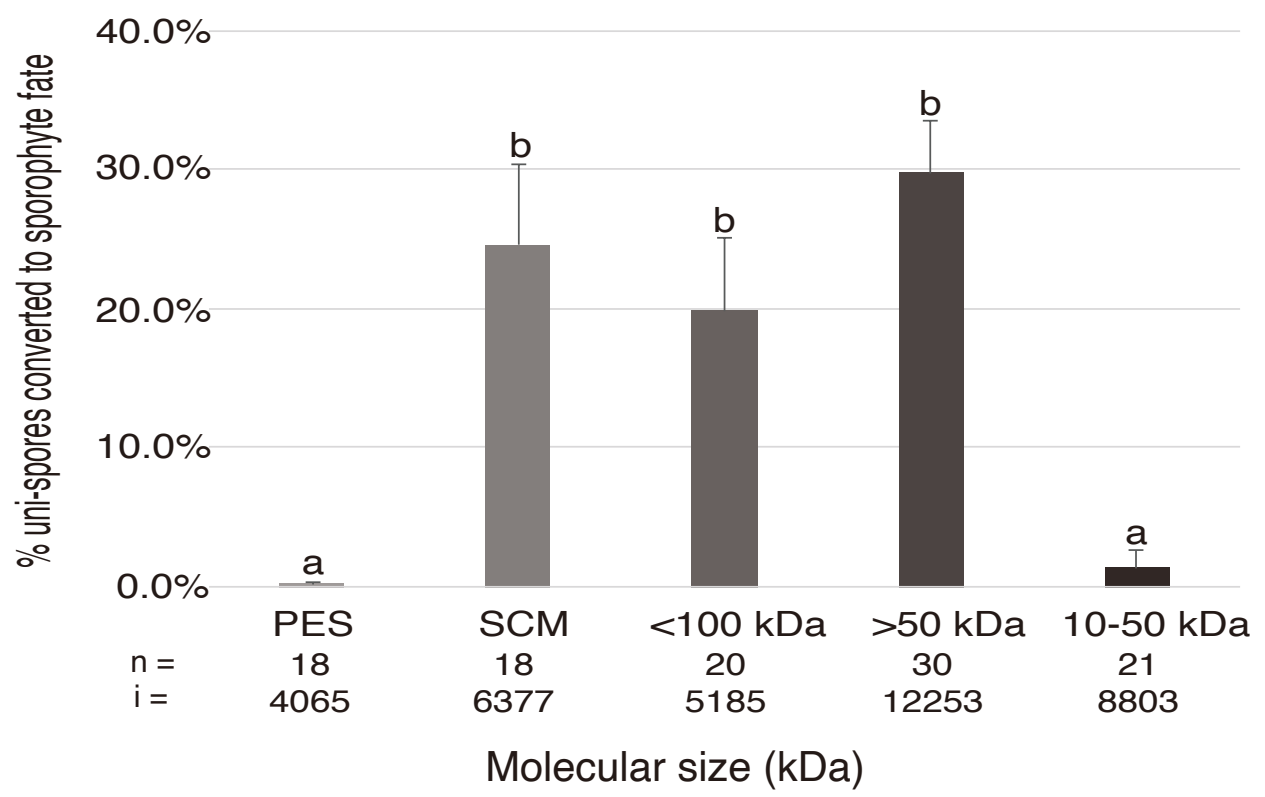

539 Fig. 2. Sporophyte-inducing activity of different SCM size fractions. (A) Size fractionation of SCM using 540 ultrafiltration. The diagrams indicate input, flow through and retentate volumes. Washes with deionised 541 water were carried out after completion of SCM filtration and the retentate volumes correspond to the final 
542 volumes after washing where relevant. The degree to which a sample was concentrated following 543 ultrafiltration is indicated by the number in brackets under the text indicating the molecular sizes of 544 molecules in the recovered samples, e.g. $(5 \mathrm{x}), 10-50 \mathrm{kDa}$ molecules were concentrated 5-fold compared to 545 the initial SCM preparation before filtration. (B) SCM size fractions, separated by ultrafiltration, were tested 546 on uni-spores for sporophyte-inducing activity. All samples were diluted to a concentration equivalent to $1 \mathrm{X}$ 547 SCM before carrying out the bioassays. Error bars indicate standard error of the mean, letters above bars 548 indicate significant differences (Wilcoxon-Mann-Whitney test, $p$-value $<0.05$; see table $\mathrm{S} 2$ for details of 549 statistical tests). PES, Provasoli-enriched natural seawater; SCM, sporophyte-conditioned medium; n, 550 number of replicates; i, number of individual germlings counted. 
A

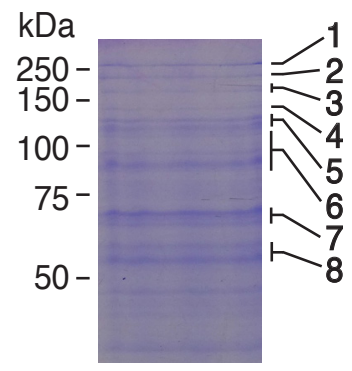

B

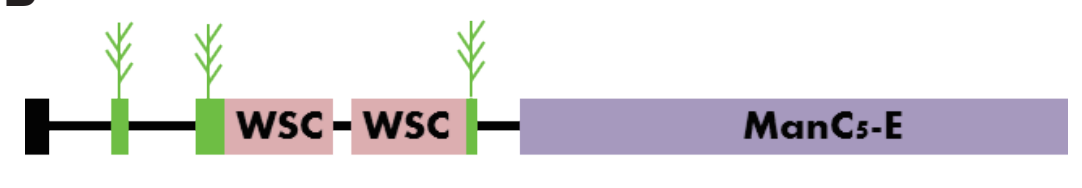

EC-20_004700 (MW: $93.6 \mathrm{kDa})$
555

556 Fig. 3. Identification of candidate proteins for the diffusible sporophyte-inducing factor by mass

557 spectroscopy analysis of protein bands detected in the $>30 \mathrm{kDa}$ fraction of concentrated SCM. (A)

558 Coomassie stained SDS-PAGE gel showing the protein bands detected in concentrated SCM. Numbers and

559 bars on the right indicate the fragments that were excised for mass spectrometry analysis. (B) Domain

560 structure of the Ec-20_004700 protein. Green boxes indicate AGP protein cores with putative attached 561 glycan groups. The Ec-20_004700 protein was detected in band 4. 


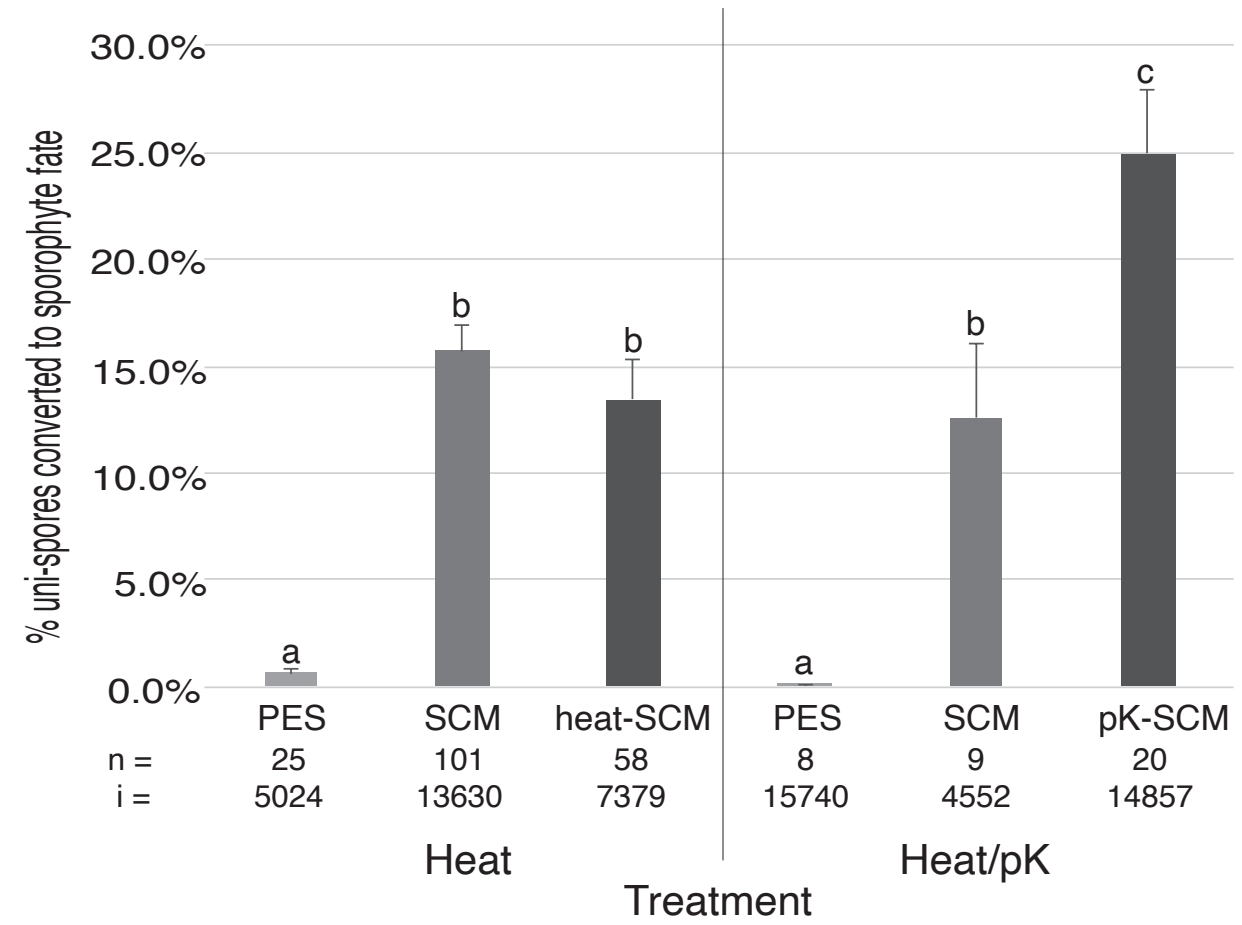

567 Fig. 4. Effect of heat and proteinase K treatment on the sporophyte-inducing factor. SCM was autoclaved at $568121^{\circ} \mathrm{C}$ for $20 \mathrm{~min}$ (right panel) or incubated with proteinase $\mathrm{K}(100 \mu \mathrm{g} / \mathrm{ml})$ at $37^{\circ} \mathrm{C}$ for $1 \mathrm{~h}$ followed by 569 autoclaving at $121^{\circ} \mathrm{C}$ for $20 \mathrm{~min}$ (left panel). Error bars indicate standard error of the mean, letters above 570 bars indicate significant differences (Wilcoxon-Mann-Whitney test, $p$-value $<0.05$; see table S3 for details of 571 the statistical tests). PES, Provasoli-enriched natural seawater; SCM, sporophyte-conditioned medium; pK572 SCM, proteinase K and heat treated SCM; heat-SCM, heat treated SCM; n, number of replicates; i, number 573 of individual germlings counted. 


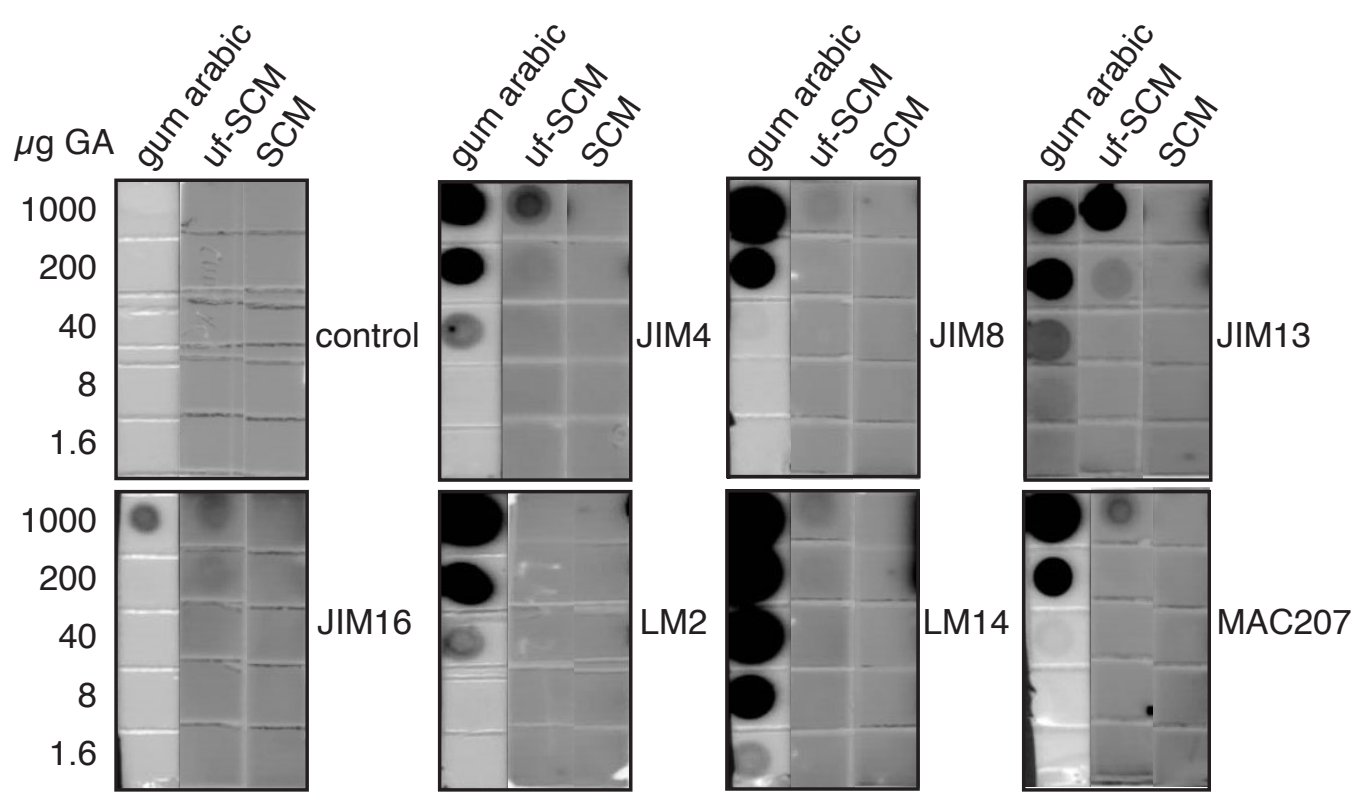

579 Fig. 5. Detection of AGP epitopes in sporophyte-conditioned medium. Samples were serially diluted in five 580 steps of five-fold dilution and $1 \mu \mathrm{l}$ of each dilution spotted for testing with the anti-AGP monoclonal 581 antibodies JIM4, JIM8, JIM13, JIM16, LM2, LM14 and MAC207. Gum arabic (starting concentration 1 $582 \mathrm{mg} / \mathrm{ml}$ ) was used as a positive control. Molecules $>50 \mathrm{kDa}$ were 400 -fold more concentrated in the neat uf583 SCM sample compared to the neat SCM sample. GA, gum arabic; SCM, sporophyte-conditioned medium; 584 uf-SCM, ultrafiltrated SCM; control, no primary antibody. 


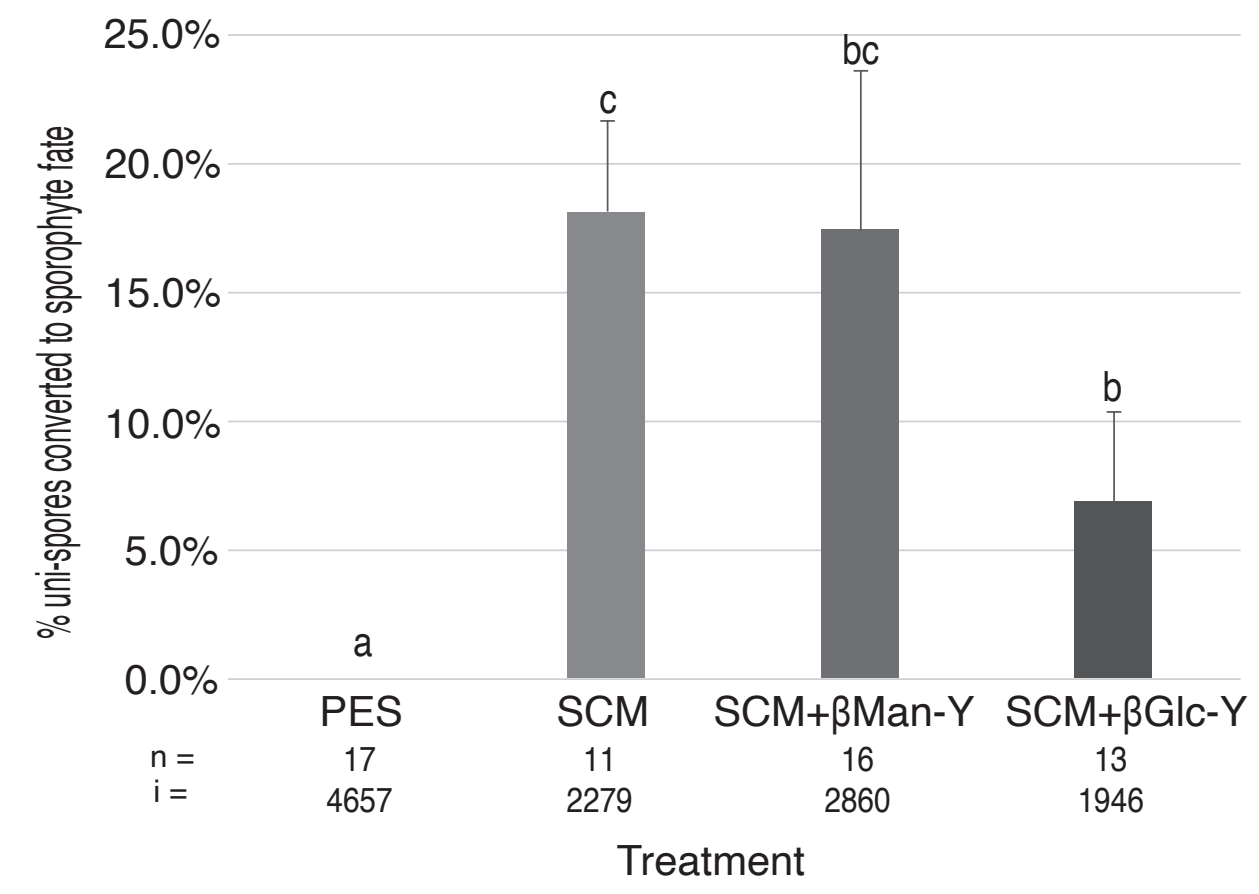

590 Fig. 6. Inhibition of the sporophyte-inducing activity of SCM following addition of a Yariv reagent. SCM 591 was incubated with either $\beta$-D-glucosyl Yariv reagent or with $\beta$-D-mannosyl Yariv reagent as a control. 592 Error bars indicate standard error of the mean, letters above bars indicate significant differences (Wilcoxon593 Mann-Whitney test, $p$-value $<0.05$; see table S4 for details of the statistical tests). PES, Provasoli-enriched 594 natural seawater; SCM, sporophyte-conditioned medium; $\beta$ Glc-Y, $\beta$-D-glucosyl Yariv reagent; $\beta$ Man-Y, $\beta$ 595 D-mannosyl Yariv reagent; n, number of replicates; i, number of individual germlings counted. 
600 Table S1. Pairwise Wilcoxon-Mann-Whitney tests comparing the levels of conversion to the sporophyte 601 generation by the diffusible factor under different experimental conditions. Refers to Fig. 1. PES, Provasoli602 enriched natural seawater; SCM, sporophyte-conditioned medium; LL, low light; NL, normal light; HL, high 603 light.

604

\begin{tabular}{|c|c|c|}
\hline comparison & $W$ & adjusted $p$-value \\
\hline \multicolumn{3}{|l|}{ Fig. 1A } \\
\hline $\operatorname{PES}(<24 \mathrm{~h}) / \mathrm{SCM}(<24 \mathrm{~h})$ & 399.5 & 0.0154 \\
\hline $\operatorname{PES}(<24 \mathrm{~h}) / \mathrm{PES}(24-48 \mathrm{~h})$ & 679 & 0.0170 \\
\hline PES (<24h) / SCM (24-48hs) & 816 & 1.0000 \\
\hline $\operatorname{PES}(<24 \mathrm{~h}) / \mathrm{PES}(>48 \mathrm{hc})$ & 707.5 & 0.0273 \\
\hline $\operatorname{PES}(<24 \mathrm{~h}) / \operatorname{SCM}(>48 \mathrm{hs})$ & 568.5 & 1.0000 \\
\hline $\operatorname{SCM}(<24 \mathrm{~h}) /$ PES $(24-48 \mathrm{hc})$ & 1180.5 & $2.0 \mathrm{e}^{-06}$ \\
\hline $\operatorname{SCM}(<24 \mathrm{~h}) / \operatorname{SCM}(24-48 \mathrm{hs})$ & 1614.5 & 0.1277 \\
\hline $\operatorname{SCM}(<24 \mathrm{~h}) / \mathrm{PES}(>48 \mathrm{hc})$ & 1241.5 & $2.3 \mathrm{e}^{-05}$ \\
\hline $\operatorname{SCM}(<24 \mathrm{~h}) / \operatorname{SCM}(>48 \mathrm{hs})$ & 1120 & 0.0313 \\
\hline PES (24-48h) / SCM (24-48hs) & 607 & 0.0027 \\
\hline PES (24-48h) / PES (>48hc) & 563 & 1.0000 \\
\hline PES (24-48h) / SCM >48hs & 427 & 0.0166 \\
\hline SCM (24-48hs) / PES (>48hc) & 1402 & 0.0042 \\
\hline SCM (24-48hs) / SCM >48hs & 1206.5 & 1.0000 \\
\hline $\operatorname{PES}(>48 \mathrm{hc}) / \mathrm{SCM}(>48 \mathrm{hs})$ & 466.5 & 0.0 \\
\hline \multicolumn{3}{|l|}{ Fig. 1B } \\
\hline PES / 0 weeks & 282 & $5.1 \mathrm{e}^{-11}$ \\
\hline PES / 1 weeks & 41 & $6.1 \mathrm{e}^{-07}$ \\
\hline PES / 3 weeks & 437 & $1.7 \mathrm{e}^{-11}$ \\
\hline PES / 5 weeks & 63.5 & $2.6 \mathrm{e}^{-13}$ \\
\hline PES / 8 weeks & 2 & $3.5 \mathrm{e}^{-06}$ \\
\hline 0 weeks / 1 weeks & 138 & 1.0000 \\
\hline 0 weeks / 3 weeks & 482 & 1.0000 \\
\hline 0 weeks / 5 weeks & 145 & 0.0326 \\
\hline 0 weeks / 8 weeks & 32.5 & 0.1234 \\
\hline 1 weeks / 3 weeks & 133.5 & 1.0000 \\
\hline 1 weeks / 5 weeks & 29 & 0.0289 \\
\hline 1 weeks / 8 weeks & 4 & 0.0541 \\
\hline 3 weeks / 5 weeks & 162.5 & 0.0052 \\
\hline 3 weeks / 8 weeks & 40.5 & 0.1068 \\
\hline 5 weeks / 8 weeks & 64.5 & 1.0000 \\
\hline \multicolumn{3}{|l|}{ Fig. 1C } \\
\hline PES / 0 weeks & 954.5 & $1.3 \mathrm{e}^{-11}$ \\
\hline
\end{tabular}




\begin{tabular}{|c|c|c|}
\hline PES / 1 weeks & 316 & $4.0 \mathrm{e}^{-07}$ \\
\hline PES / 3 weeks & 326 & $1.2 \mathrm{e}^{-07}$ \\
\hline PES / 5 weeks & 241 & $8.8 \mathrm{e}^{-12}$ \\
\hline PES / 8 weeks & 573.5 & 0.0002 \\
\hline 0 weeks / 1 weeks & 1086 & 1.0000 \\
\hline 0 weeks / 3 weeks & 1196 & 1.0000 \\
\hline 0 weeks / 5 weeks & 1394 & 1.0000 \\
\hline 0 weeks / 8 weeks & 1577.5 & 0.0346 \\
\hline 1 weeks / 3 weeks & 409.5 & 1.0000 \\
\hline 1 weeks / 5 weeks & 431 & 1.0000 \\
\hline 1 weeks / 8 weeks & 586 & 0.0705 \\
\hline 3 weeks / 5 weeks & 457.5 & 1.0000 \\
\hline 3 weeks / 8 weeks & 605 & 0.1484 \\
\hline 5 weeks / 8 weeks & 830 & 0.0061 \\
\hline \multicolumn{3}{|l|}{ Fig. 1D } \\
\hline PES / 4 weeks & 1116.5 & 0.00221 \\
\hline PES / 6 weeks & 195.5 & $6.6 \mathrm{e}^{-11}$ \\
\hline PES / 8 weeks & 131.5 & $2.6 \mathrm{e}^{-12}$ \\
\hline PES / 10 weeks & 1058.5 & 0.42732 \\
\hline 4 weeks / 6 weeks & 190 & 0.00473 \\
\hline 4 weeks / 8 weeks & 142.5 & 0.00040 \\
\hline 4 weeks / 10 weeks & 511.5 & 0.32191 \\
\hline 6 weeks / 8 weeks & 173 & 0.32191 \\
\hline 6 weeks / 10 weeks & 434 & 0.00066 \\
\hline 8 weeks / 10 weeks & 456.5 & 0.00011 \\
\hline \multicolumn{3}{|l|}{ Fig. 1E } \\
\hline PES / LL & 938 & $1.501 \mathrm{e}^{-05}$ \\
\hline PES / NL & 610.5 & 0.000 \\
\hline $\mathrm{PES} / \mathrm{HL}$ & 233.5 & $1.134 \mathrm{e}^{-05}$ \\
\hline LL / NL & 1461 & 0.429 \\
\hline LL / HL & 785.5 & 0.166 \\
\hline NL / HL & 571.5 & 0.662 \\
\hline
\end{tabular}

606 Table S2. Pairwise Wilcoxon-Mann-Whitney tests comparing the levels of conversion to the sporophyte 607 generation induced by treatment with different SCM size fractions. Refers to Fig. 2. PES, Provasoli-enriched 608 natural seawater; SCM, sporophyte-conditioned medium; kDa, kiloDaltons. 609

\begin{tabular}{|cc|c|c|}
\hline \multicolumn{2}{|c|}{ comparison } & $W$ & adjusted $p$-value \\
\hline Fig. 2 & 14 & $1.5 \mathrm{e}^{-05}$ \\
& & & 0.00032 \\
& PES / SCM & 45 & $3.5 \mathrm{e}^{-07}$ \\
& PES / $<100 \mathrm{kDa}$ & 0 & 1.0000 \\
& PES / 10-50 kDa & 202 & \\
\hline
\end{tabular}




\begin{tabular}{|c|c|c|}
\hline $\mathrm{SCM} /<100 \mathrm{kDa}$ & 208 & 1.0000 \\
$\mathrm{SCM} />50 \mathrm{kDa}$ & 209 & 1.0000 \\
$\mathrm{SCM} / 10-50 \mathrm{kDa}$ & 354 & $1.0 \mathrm{e}^{-05}$ \\
$<100 \mathrm{kDa} />50 \mathrm{kDa}$ & 197.5 & 1.0000 \\
$<100 \mathrm{kDa} / 10-50 \mathrm{kDa}$ & 362.5 & 0.00018 \\
$>50 \mathrm{kDa} / 10-50 \mathrm{kDa}$ & 614 & $4.3 \mathrm{e}^{-07}$ \\
\hline
\end{tabular}

611 Table S3. Pairwise Wilcoxon-Mann-Whitney tests comparing the effects of heat and proteinase K treatments 612 on levels of conversion to the sporophyte generation by the diffusible factor. Refers to Fig. 4. PES,

613 Provasoli-enriched natural seawater; SCM, sporophyte-conditioned medium; pk, proteinase K.

614

\begin{tabular}{|cc|c|c|}
\hline \multicolumn{2}{|c|}{ comparison } & $W$ & adjusted $p$-value \\
\hline Fig. 4 & & \\
& PES / SCM & 165.5 & $5.1 \mathrm{e}^{-11}$ \\
& 86.5 & $3.7 \mathrm{e}^{-10}$ \\
PES / heat-SCM & 3385.5 & 0.1 \\
SCM / heat-SCM & 0 & 0.00059 \\
PES / SCM & 0 & 0.00013 \\
PES / pk-SCM & 45.5 & 0.03785 \\
SCM / pk-SCM & \\
\hline
\end{tabular}

616 Table S4. Pairwise Wilcoxon-Mann-Whitney tests comparing the effects of treatments with different Yariv 617 reagents on levels of conversion to the sporophyte generation by the diffusible factor. Refers to Fig. 6. PES, 618 Provasoli-enriched natural seawater; SCM, sporophyte-conditioned medium; $\beta$ Glc-Y, $\beta$-D-glucosyl Yariv 619 reagent; $\beta$ Man-Y, $\beta$-D-mannosyl Yariv reagent.

620

\begin{tabular}{|c|c|c|}
\hline comparison & $W$ & adjusted $p$-value \\
\hline \multicolumn{3}{|l|}{ Fig. 6} \\
\hline PES / SCM & 1.5 & $2.4 \mathrm{e}^{-05}$ \\
\hline PES / SCM+ $\beta$ Man-Y & 44.5 & 0.0016 \\
\hline $\mathrm{PES} / \mathrm{SCM}+\beta \mathrm{Glc}-\mathrm{Y}$ & 44.5 & 0.0075 \\
\hline $\mathrm{SCM} / \mathrm{SCM}+\beta \mathrm{Man}-\mathrm{Y}$ & 111 & 0.5305 \\
\hline $\mathrm{SCM} / \mathrm{SCM}+\beta \mathrm{Glc}-\mathrm{Y}$ & 115 & 0.0369 \\
\hline $\mathrm{SCM}+\beta \mathrm{Man}-\mathrm{Y} / \mathrm{SCM}+\beta \mathrm{Glc}-\mathrm{Y}$ & 127.5 & 0.5305 \\
\hline
\end{tabular}

